УДК 81'367=811.111'04/06

DOI https://doi.org/10.32447/2663-340X-2019-6-1

\title{
FROM SOV TO SVO: A COMPLETE BREAKDOWN IN LAW AND ORDER?
}

\author{
Viktória Albert \\ PhD in Linguistics, \\ Full Professor at the Department of the English Language and Literature, \\ Kodolányi János University, \\ Frangepán str., 50-56, 1139 Budapest, Hungary
}

\begin{abstract}
The present article attempts to shed light on the external and internal influences behind the shift of synthetic SOV towards analytic SVO word order pattern. Furthermore, it also discusses a variety of reasons why SOV remained around for so long well into the Middle and Early New English periods. There is a general consensus that the right-branching SVO word order is universally preferred over an SOV order. The shift from a SOV to an SVO word order, which is basically the change from a verb-final word order towards a word order in which the verb is placed in the medial position, is one of the most elaborate and striking in the history of Indo-European languages with English being one of them. The SOV word order stayed around for centuries in English mainly because of the strong Latin and Christian influence. When England was converted by the Romans, not only was the new religion introduced but also the Bible and, of course, Latin. In the years that followed, many churches, monasteries, and scriptoria were built across the country where monks, priests, and scribes were educated to read and write in Latin in order to be able to preach Christianity together with the Roman missionaries. So, the sole language of the Church became Latin which was unknown to almost $99 \%$ of the population of England.

Key words: language change, word order, Latin, SOV (subject-object-verb), SVO (subject-verb-object), Old Norse, Old English, Middle English, Early New English.
\end{abstract}

Introduction. Unlike before the 1960's, the past decades of the $20^{\text {th }}$ and $21^{\text {st }}$ centuries are characterized by a considerable attention to sentence study in diachronic and synchronic perspective and especially to the shift of dominant word order in the Old and Middle English simple sentence. A relatively large number of outstanding linguists $[7 ; 8 ; 9 ; 11 ; 12 ; 15 ; 17$; $18 ; 25]$ have dealt and still deal with this topic each attempting to identify the major causes and outcomes of grammaticalization which is "not only a syntactic change, but a global change affecting also the morphology, phonology, and semantics" $[21,160]$.

The purpose of the study. The principle goals of this article are to discuss the indispensable role of the Latin influence and several limitations regarding the first translations of the Bible into English in maintaining the SOV word order whilst the language had already been drifting towards the SVO due to the levelling and disappearance of morphological inflections. Since this process resulted in the coexistence of various word order patterns in the simple sentence during the Old and Middle English periods, the paper further aims to show that the changes of such tremendous scope are not abrupt, but rather measured and consistent.

Methods of the research: philosophical enquiry which allows to critically analyse and synthesise research conducted in the field of word order development in English.

Research findings. Since language is dynamic and it is constantly changing, this means that this change can "affect an entire system or subsystem of the language" $[23,9]$ and at a various pace. In other words, "Generation by generation, pronunciations evolve, new words are borrowed or invented, the meaning of old words drifts, and morphology develops or decays. The rate of change may vary from one place to another but whether the changes are faster or slower, they do happen and they happen for a good cause" $[16 ; 20,1]$. Slowly but steadily, "they build up until the "mother tongue" becomes arbitrarily distant and different. After a thousand years, the original and new languages will not be mutually intelligible" [27].

Besides, one tiny language change may result in a series of events leading to the restructuring of the whole language system, but in a way that these alterations will become interdependent and reciprocal. Thereby, it was the stress shift from the last to the first syllable in Proto-Indo-European language which triggered this long-lasting and systematic change. Gradually, initiating certain morphological reorganization, the stress shift managed to completely transform the syntax of the English language.

There is a general consensus that the right-branching SVO word order is universally preferred over an SOV order. The shift from a SOV to an SVO word order, which is basically the change from a verb-final word order towards a word order in which the verb is placed in the medial position, is one of the most elaborate and striking in the history of Indo-European languages with English being one of them. $\mathrm{Li}$, for instance, also supports this view and regards this shift as "the most drastic and complex category of syntactic change" [19,2].

According to many accounts, Old English is an $\mathrm{OV}$, that is a verb-final, language, and the movement from $\mathrm{OV}$ to $\mathrm{VO}$ is usually described as an abrupt grammatical reanalysis occurring at a definite period in Old English. Of course, there is no such thing as 
"a certain point" because "it should be obvious that a language cannot change its basic word order overnight" $[9,17299]$. Yet, languages do not work that way. A change of such kind does not happen suddenly and in all the dialects simultaneously, but it rather entails a transition period of a certain duration which involves a "synchronic competition between two grammars" [25, 258].

Normally, there is a phase in which more several word orders are used in between periods of relatively rigid word order. Word order change is then all about frequency of use. The word sequence that is used the most in this period of comparatively "free" or flexible word order slowly establishes itself as the new basic word order of a language simply because it is reanalysed as such when the former is used less and less frequently $[9 ; 25]$. This switch begins before Old English and continues well into the Middle English period and onwards.

Historically, SOV is a much older word order. Old English inherited it from Proto-Indo-European, which sustained all through Old Germanic. In his own words, Givón concludes that the overwhelming majority of languages which currently do not exhibit any traces of SOV syntax "can be reconstructed via a judicious use of internal and comparative methods, to a period usually not earlier than $6000-7000$ B.C." $[10,275]$. Hence, the VO grammar, which is "derivable from OV base structure" $[7,150]$, emerges early in the Old English period, and competes with the old existing OV grammar throughout these periods until the old system decays.

However, it does not mean that SVO is non-existent in Old English. In fact, there is countless evidence of this pattern's recruitment in literary texts throughout this period, but it is not yet as commonplace as the verb-final word order $[4,44 ; 14,87-90]$. By the end of Old English, a tendency towards verb-second order can be clearly observed, and during Middle English this process speeds up as a response to the demise of many grammatical inflections.

Indeed, if nouns, adjectives, verbs, and adverbs no longer contain much grammatical information that inevitably leads to an ambiguous structure, the language system immediately responds and initiates a compensation for this loss of information in order to maintain clarity once provided by the inflections. For instance, The girl likes the cat can be interpreted as SVO or OVS. As a result, turning to analytical means appears quite practical and becomes fundamental. Therefore, the application of prepositions, auxiliaries and, finally, the fixation of SVO word order secure the relationship among constituents in the sentence by eliminating morphological ambiguity between the subject and the object $[6 ; 12]$. Due to this case syncretism, Modern English, even though exhibiting some remnants of $\mathrm{OV}$, is surely a VO language and relies heavily on word order to convey essential grammatical information.

Why was SOV in use for so long? The SOV word order stayed around for centuries in English mainly because of the strong Latin and Christian influence. When England was converted by the Romans, not only was the new religion introduced but also the Bible and, of course, Latin. In the years that followed, many churches, monasteries, and scriptoria were built across the country where monks, priests, and scribes were educated to read and write in Latin in order to be able to preach Christianity together with the Roman missionaries. So, the sole language of the Church became Latin which was unknown to almost $99 \%$ of the population of England.

Nevertheless, the Church intentionally kept the Bible out of reach for its devotees. According to Foot, the Church aspired to supervise every single aspect of every member of the population's lives. As a matter of fact, "the Church regulated lives by controlling what people did during the day and what they did in bed" [3]. That is why, it forbade its translation into English and discouraged people from reading and interpreting it for the fear that it would be perceived in a way that may not be favourable for the Church.

Moreover, the scribes were not very competent either in Latin or Greek. The absence of reliable mono- and bilingual dictionaries was another setback that put many scribes off this activity since they dreaded to twist or falsify the Word of God. In addition, early Old English and Latin shared similar grammars both operating with a very well-developed inflectional system and similar OV word order [2].

It is noteworthy that Old English was already evolving towards the VO-type due to the grammaticalization of its word order towards the end of this period. Nonetheless, the translators were expected to demonstrate a strong adherence to the syntax and vocabulary of the original texts. In most cases, they did keep the verb-final word order well into Middle English for the above stated reasons. Consequently, when some translators tried to retain the Latin word order in their translations, it made no sense in English.

The translators' attempt to move the literary texts towards the reader was quite a long ordeal due to a large number of limitations. But some were in favour of making their texts more available and made more concessions to the grammar of English by reflecting the teachings of the Bible through spoken word. Such improvement ensured that the laypeople were able to comprehend and, thus, cultivate a personal relationship with God [2].

As it can be seen, not all the translators were apprehensive of the Church and its bloody persecutions but were rather daring and recognized the Bible's indispensable role in ordinary people's lives. They had courage and means to modify the text of the Bible in order to bring it closer to ordinary English people even though they knew they risked severe judgement by the Church, persecution, or even death [2].

Why did the word order change? According to Aitchison, the causes of such linguistic change can be divided into two broad categories. On the one hand, "there are external sociolinguistic factors that is, social factors outside the language system. 
On the other hand, there are internal psycholinguistic ones - that is, linguistic and psychological factors which reside in the structure of the language and the minds of the speakers" $[1,134]$.

Clearly, there were also certain internal and external forces which triggered the switch to a VO order in English. As it has been mentioned above, the restructuring of the whole system towards SVO had already begun in Proto-Germanic due to the stress shift initiating their morphological fading and then to the loss of endings resulting in the final fixing of SVO. Thus, the language was gradually losing its synthetic character and was turning analytic, where grammatical relationships in the sentence started to be expressed by a stricter word order implementing the large use of prepositions and auxiliaries [4, 32; 7, 49].

Conversely, English was subject to different external influences which acted as distinct triggers for the development of VO. In this sense, Norman French did not bring any significant syntactic innovations that were as striking as the introduction of new lexical items [11, 21]. Old Norse, for instance, exercising a substantial influence on English, was also a synthetic language and had a complex system of suffixes. When the Vikings arrived in Britain, their task was to communicate with the Anglo-Saxons as this was primarily "an oral world" [22]. Generally, all language changes emerge in speech first, and only after are they introduced in writing. As a result, this was the case with a VO distribution in English.

The switch towards SVO was governed by both conscious and subconscious bias. To support the view expressed above, Crystal in his You Say Potato speaks about "accent accommodation" also known as "accent buddies" [5]. He emphasizes that people are prone to change their way of speaking several times during their lifetime. This means that this switch can be conscious, ie., when the speaker is governed by the feeling of shame towards one's own accent or dialect, or by the desire to fit in. Alternatively, this change can also be subconscious, that is with no specific intent on the speaker's side. So the claim: "I will sound a bit more like you, and you will sound a bit more like me, and it is the accent way of saying, "We are buddies"' [5] appears to be more than relevant in such circumstances, and one can speak of "dialect accommodation" as well.

Therefore, as Hickey puts it, "contact situations have a number of further consequences for the languages involved. If contact is accompanied by extensive bilingualism then there is a distinct tendency for both languages to simplify morphologically to a more analytic type" $[13,53]$.

In support of this theory, it is necessary to mention that the Old Norse and English roots were more similar than their inflections. When these peoples talked to each other, all those inflections must have been very confusing for both parties. As this being quite tempting, the speakers of Old English and Old Norse just started to leave the endings off consciously and subconsciously in order to facilitate comprehensibility and communication since the languages at that point were mutually intelligible "on account of their close relationship within the family of Germanic languages" $[26,82 ; 22]$. This certainly led to the implementation of the restricted SVO word order accompanied by the extensive use of prepositions and auxiliaries in order to avoid miscommunication.

Additionally, in those places where the Vikings were densely concentrated, intermarriages were quite common, and children who were born into such families became the native speakers of this rendered and "incomplete English" [22]. To endorse this view, much written evidence has been found which attests to the fact that the loss of endings started exactly in the Northumbrian dialect spoken in the very same area where these foreigners were accumulated. This implies that all these oral linguistic innovations occurred in the North first, but towards the end of the Middle English period spread across the country and, finally, were codified in writing.

Of course, this would not have happened without the speakers of the language. In this case the anthropological perspective related to language change seems quite relevant. Quoting Ottenheimer, "There are many factors influencing the rate at which language changes, including the attitudes of the speakers toward borrowing change. When most members of a speech community value novelty, for example, their language will change more quickly. When most members of a speech community value stability, then their language will change more slowly. When a particular pronunciation or word or grammatical form or turn of phrase is regarded as more desirable, or marks its users as more important or powerful, then it will be adopted and imitated more rapidly than otherwise... The main thing to remember about change is that, as long as people are using a language, that language will undergo some change" $[24,276]$.

Conclusions. Overall, it is important to highlight that the loss of endings in English is not ultimately the result of contact with Old Norse. The Scandinavians just reinforced and accelerated the internal process which had already begun in Old Germanic caused by the stress shift in Proto-Indo-European dialect. Due to the dialect contact between northern and southern varieties of English, the word order started to gradually manifest the same innovative features in all the dialects. This new feature which appeared in speech first, centuries later became the correct usage and was codified in writing as standard. All things considered, this was the perfect "recipe for what eventually became Modern English" [22].

Further research within word order change in English could include, for instance, studying these developments in a diachronic perspective based on the non-extended and extended types of the absolute infinitive construction in Middle English, Early New English and Modern English. 


\section{ЛITЕРАТУРА}

1. Aitchison, J. (2001). Language Change: Progress or Decay? 3rd ed. Cambridge University Press.

2. Albert, V. (2018). On the margins of translation: a brief overview of early manuscript production and translation in Britain. Freeside Europe Online Academic Journal, Kodolányi János University. Issue 8. Retrieved from: http://www.kodolanyi.hu/freeside/issues/issue8

3. Christianity in Britain. (2014). BBC: Religions. Retrieved from: https://www.bbc.co.uk/religion/religions/ christianity/history/uk 1.shtml.

4. Crystal,D.(2003). Cambridge Encyclopediaof the EnglishLanguage. Cambridge:CambridgeUniversity Press. 499p.

5. Crystal, D., Crystal, B. (2014). You Say Potato. A Book About Accents. London: Macmillan Publishers Ltd.

6. Dunton-Downer, L. (2010). The English Is Coming!: How One Language Is Sweeping the World. New York: Simon \& Schuster. 326 p.

7. Fischer, O. et al. (2000). The Syntax of Early English. Cambridge: Cambridge University Press. 340 p.

8. Gelderen, E. van. (2018). Analyzing Syntax Through Texts: Old, Middle, and Early Modern English. Edinburgh University Press Ltd. $192 \mathrm{p}$.

9. Gell-Mann, M., Ruhlen, M. (2011). The Origin and Evolution of Word Order. Proceedings of the National Academy of Sciences, 108, 17290-17295. Retrieved from: https://www.ncbi.nlm.nih.gov/pmc/articles/ PMC3198322/; https://doi.org/10.1073/pnas.1113716108

10. Givón, T. (1979). On Understanding Grammar. New York: Academic Press. 271-305.

11. Haeberli, E. (2002). Inflectional Morphology and the Loss of Verb Second in English. In: Syntactic Effects of Morphological Change. Ed. by D. Lightfoot. Oxford: Oxford University Press. 88-106.

12. Hawkins, J. A. (2015). A Comparative Typology of English and German: Unifying the Contrasts. Routledge.

13. Hickey, R. Language Change. 2-62. Retrieved from: https://www.uni-due.de/ELE/LanguageChange.pdf.

14. Hogg, R. (2002). An Introduction to Old English. Edinburgh University Press. 163 p.

15. Ingham, R. (2005). Bilingualism and Syntactic Change in Medieval England, Reading Working Papers in Linguistics 8, 1-26.

16. Jones, M. \& Singh, I. (2005). Exploring Language Change. NY: Routledge.

17. Kemenade, A. van. (1997). V2 and Embedded Topicalization in Old and Middle English. In: Parameters of Morphosyntactic Change. Ed. by A. van Kemenade and N. Vincent. Cambridge: Cambridge University Press. 326-351.

18. Kroch, A., Taylor, A. (1997). Verb Movement in Old and Middle English: Dialect Variation and Language Contact. In: Parameters of Morphosyntactic Change. Ed. by A. van Kemenade and N. Vincent. Cambridge: Cambridge University Press. 297-325.

19. Li, C. (1977). Mechanisms of Syntactic Change. Austin: University of Texas Press.

20. Mantiri, O. (2010). Factors Affecting Language Change. pdf. Retrieved from: https://dx.doi.org/10.2139/ ssrn.2566128, pdf.

21. McMahon, A. M. S. (2009). Understanding Language Change. Cambridge: Cambridge University Press. 361 p.

22. McWhorter, J. (2008). Our Magnificent Bastard Tongue: The Untold History of English. New York: Penguin Group Inc. pdf.

23. Millward, C. M. (1996). A Biography of the English Language. 2nd ed. Harcourt Brace. 479 p.

24. Ottenheimer, H. J. (2009). The Anthropology of Language: An Introduction to Linguistic Anthropology, 2nd ed. Belmont: Wadsworth. $372 \mathrm{p}$.

25. Pitzuk, S. (1996). Old English Verb-Complement Word Order and the Change from OV to VO. York Papers in Linguistics 17: 241-264.

26. Townend, M. (2006). Contacts and Conflicts: Latin, Norse, and French. In: The Oxford History of English. Ed. by Lynda Mugglestone. Oxford: Oxford University Press. 61-85.

27. Types of Language Change. Lectures. Retrieved from: https://www.ling.

28. upenn.edu/courses/Fall_2003/ling001/language_change.html.

\section{REFERENCES}

1. Aitchison, J. (2001). Language Change: Progress or Decay? 3rd ed. Cambridge University Press.

2. Albert, V. (2018). On the margins of translation: a brief overview of early manuscript production and translation in Britain. Freeside Europe Online Academic Journal, Kodolányi János University. Issue 8. Retrieved from: http://www.kodolanyi.hu/freeside/issues/issue8.

3. Christianity in Britain. (2014). BBC: Religions. Retrieved from: https://www.bbc.co.uk/religion/religions/christianity/history/uk_1.shtml

4. Crystal, $\bar{D}$.(2003).Cambridge Encyclopediaofthe EnglishLanguage. Cambridge:CambridgeUniversity Press. $499 \mathrm{p}$.

5. Crystal, D., Crystal, B. (2014). You Say Potato. A Book About Accents. London: Macmillan Publishers Ltd.

6. Dunton-Downer, L. (2010). The English Is Coming!: How One Language Is Sweeping the World. New York: Simon \& Schuster. $326 \mathrm{p}$.

7. Fischer, O. et al. (2000). The Syntax of Early English. Cambridge: Cambridge University Press. 340 p.

8. Gelderen, E. van. (2018). Analyzing Syntax Through Texts: Old, Middle, and Early Modern English. Edinburgh University Press Ltd. 192 p. 
9. Gell-Mann, M., Ruhlen, M. (2011). The Origin and Evolution of Word Order. Proceedings of the National Academy of Sciences, 108, 17290-17295. Retrieved from: https://www.ncbi.nlm.nih.gov/pmc/articles/ PMC3198322/; https://doi.org/10.1073/pnas.1113716108.

10. Givón, T. (1979). On Understanding Grammar. New York: Academic Press. 271-305.

11. Haeberli, E. (2002). Inflectional Morphology and the Loss of Verb Second in English. In: Syntactic Effects of Morphological Change. Ed. by D. Lightfoot. Oxford: Oxford University Press. 88-106.

12. Hawkins, J. A. (2015). A Comparative Typology of English and German: Unifying the Contrasts. Routledge.

13. Hickey, R. Language Change. 2-62. Retrieved from: https://www.uni-due.de/ELE/LanguageChange.pdf

14. Hogg, R. (2002). An Introduction to Old English. Edinburgh University Press. 163 p.

15. Ingham, R. (2005). Bilingualism and Syntactic Change in Medieval England, Reading Working Papers in Linguistics 8, 1-26.

16. Jones, M. \& Singh, I. (2005). Exploring Language Change. NY: Routledge.

17. Kemenade, A. van. (1997). V2 and Embedded Topicalization in Old and Middle English. In: Parameters of Morphosyntactic Change. Ed. by A. van Kemenade and N. Vincent. Cambridge: Cambridge University Press. $326-351$.

18. Kroch, A., Taylor, A. (1997). Verb Movement in Old and Middle English: Dialect Variation and Language Contact. In: Parameters of Morphosyntactic Change. Ed. by A. van Kemenade and N. Vincent. Cambridge: Cambridge University Press. 297-325.

19. Li, C. (1977). Mechanisms of Syntactic Change. Austin: University of Texas Press.

20. Mantiri, O. (2010). Factors Affecting Language Change. pdf. Retrieved from: https://dx.doi.org/10.2139/ ssrn.2566128, pdf.

21. McMahon, A. M. S. (2009). Understanding Language Change. Cambridge: Cambridge University Press. 361 p.

22. McWhorter, J. (2008). Our Magnificent Bastard Tongue: The Untold History of English. New York: Penguin Group Inc. pdf.

23. Millward, C. M. (1996). A Biography of the English Language. 2nd ed. Harcourt Brace. 479 p.

24. Ottenheimer, H. J. (2009). The Anthropology of Language: An Introduction to Linguistic Anthropology, 2nd ed. Belmont: Wadsworth. 372 p.

25. Pitzuk, S. (1996). Old English Verb-Complement Word Order and the Change from OV to VO. York Papers in Linguistics 17: 241-264.

26. Townend, M. (2006). Contacts and Conflicts: Latin, Norse, and French. In: The Oxford History of English. Ed. by Lynda Mugglestone. Oxford: Oxford University Press. 61-85.

27. Types of Language Change. Lectures. Retrieved from: https://www.ling.

28. upenn.edu/courses/Fall_2003/ling001/language_change.html.

\title{
ЗСУВ ВІД SOV ДО SVO: НЕЗВОРОТНІЙ ШЛЯХ ДО ПЕРЕВОРОТУ?
}

\author{
Альберт Вікторія \\ кандидат лінгвістики, \\ професор кафедри англійської мови та літератури, \\ Університет Кодолані Янос, \\ Франгепана, 50-56, 1139 Будапешт, Угорщина
}

\begin{abstract}
У статті досліджуються лінгвістичні та екстралінгвістичні фактори, пов 'язані зі зсувом синтетичного SOV y бік аналітичного SVO порядку слів в англійській мові. Крім того, у ході дослідження обговорюються можливі причини, через які SOV так довго вживався у середньо- та ранньоновоанглійському періоді. Існує загальна думка, щчо порядок слів правого розгалуження SVO переважає над порядком SOV. Перехід від SOV до словопорядку SVO, який, в основному, є зміною від дієслово-остаточного порядку слів на порядок слів, в якому дієслово розмішується в медіальному положенні, є одним з найбільш розроблених і яскравих в історії Індоєвропейських мов, англійська мова є однією з них. Порядок слів SOV протягом століть зберігався англійською мовою головним чином через сильний латинський та християнський вплив. Коли Англія була перетворена римлянами, була введена не тільки нова релігія, але й Біблія $і$, звичайно, латинська мова. У наступні роки по всій країні було побудовано багато иерков, монастирів та скрипторїв, де монахи, священики та книжники навчалися читати та писати латинською мовою, щоб мати змогу проповідувати християнство разом із римськими місіонерами. Так, єдиною мовою Церкви стала латинська, яка була невідома майже 99\% населення Англії.

Ключові слова: еволюиія мови, порядок слів, латинська мова, SOV (суб’'єкт-об'єкт-дієслово), SVO (суб 'єктдієслово-об 'єкт), старо-норвезька, старо-англійська, середньоанглійська та ранньоновоанглійська мови.
\end{abstract}

